\title{
Successful management of recurrent mucocele by diode laser and thermoplasticised splint as an adjunctive therapy
}

\author{
Mahesh Chinta, ${ }^{1}$ Avula Jogendra Saisankar, ${ }^{2}$ Charishma Birra, ${ }^{2}$ \\ Pratej Kiran Kanumuri ${ }^{3}$
}

${ }^{1}$ Pedodontics and Preventive Dentistry, Panineeya Mahavidyalaya Institute of Dental Sciences and Research Centre, Hyderabad, India ${ }^{2}$ Pedodontics and Preventive Dentistry, Sibar Institute of Dental Sciences, Guntur, Andhra Pradesh, India

${ }^{3}$ Panineeya Institute of Dental Sciences and Hospital, Hyderabad, Telangana, India

\section{Correspondence to} Dr Pratej Kiran Kanumuri, pratejkiran@gmail.com

Accepted 9 August 2016

\section{DESCRIPTION}

Mucoceles are the most common lesions of the minor salivary glands that occur mostly in the lower lip, ${ }^{1}$ probably due to the higher incidence of mechanical trauma in this region. ${ }^{2}$

A 9-year-old boy visited the department with symptoms of swelling on the lower lip since 15 days. The habit of nail biting was confirmed by the parents leading to notched maxillary incisors. Irritation from these notched incisors caused the

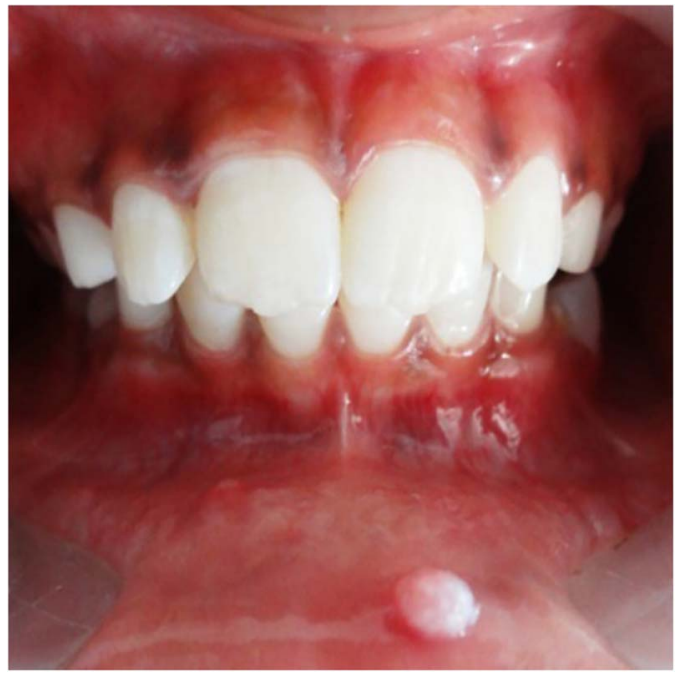

Figure 1 Mucocele on the lower lip due to notched incisors.

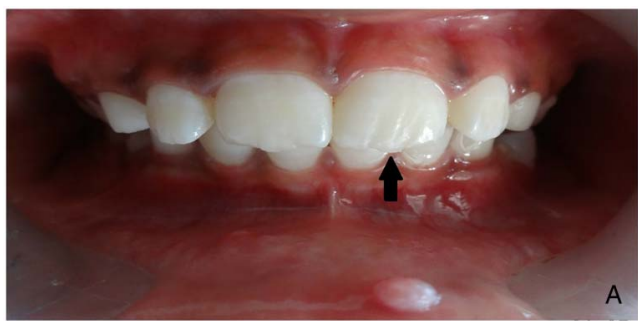

CrossMark

To cite: Chinta $\mathrm{M}$ Saisankar AJ, Birra C, et al. BMJ Case Rep Published online: [please include Day Month Year] doi:10.1136/ bcr-2016-216354

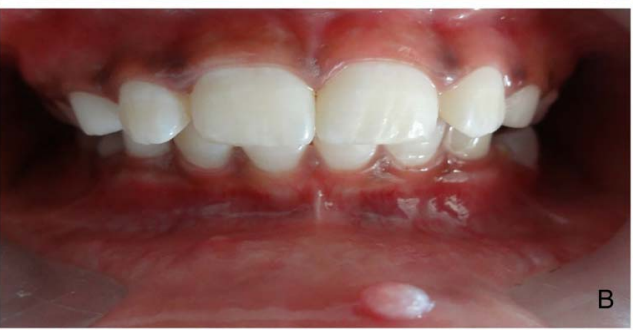

Figure 2 (A) Notched maxillary incisors. (B) Restored with composite material. swelling on the lower lip. On clinical examination the lesion appeared as a single, raised, circumscribed vesicle which was firm in consistency measuring $4 \mathrm{~mm}$ in diameter (figure 1) and there was no associated pus discharge or sinus. Considering the history and clinical findings a differential diagnosis of irritation fibroma or mucocele was noted.

The notched incisors were restored with composite material to avoid further trauma (figure 2). Diode lasers have been used in paediatric dentistry

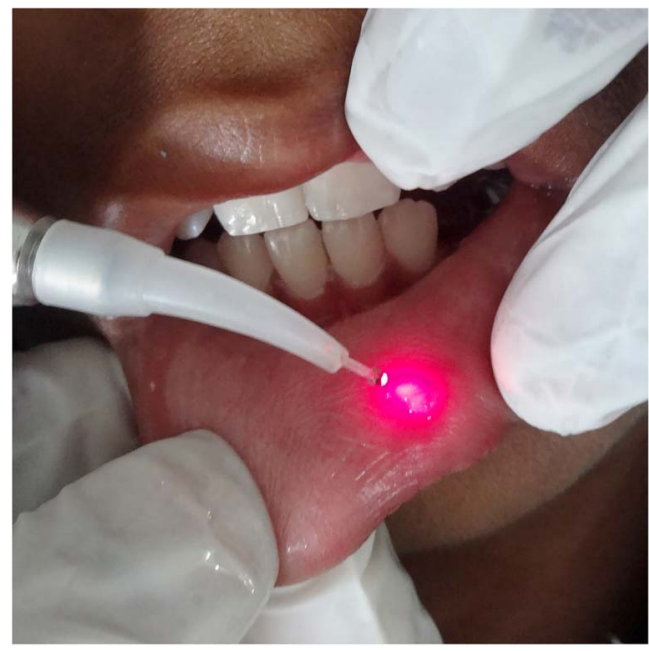

Figure 3 Removal of mucocele by diode laser tip.

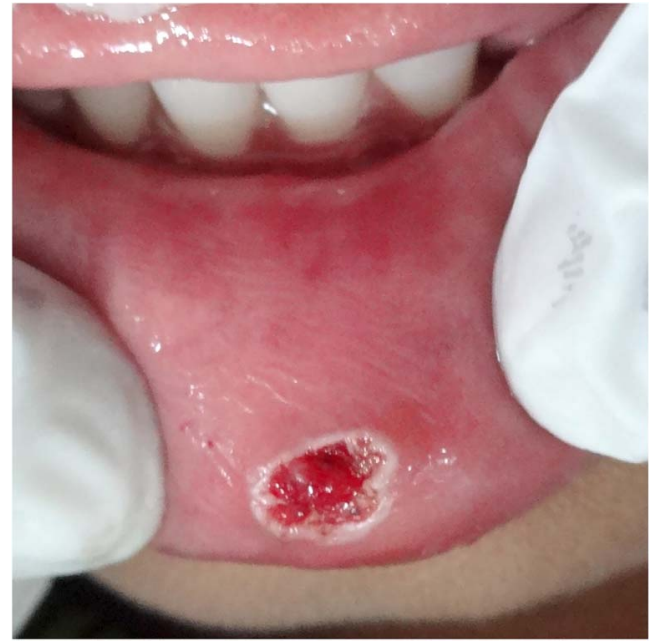

Figure 4 Coagulation was observed after the removal of the lesion. 


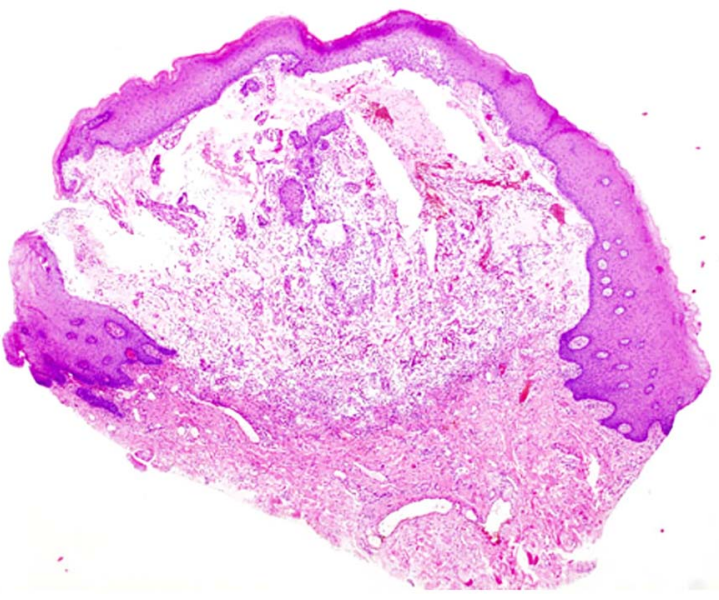

Figure 5 Histopathological examination of the lesion.

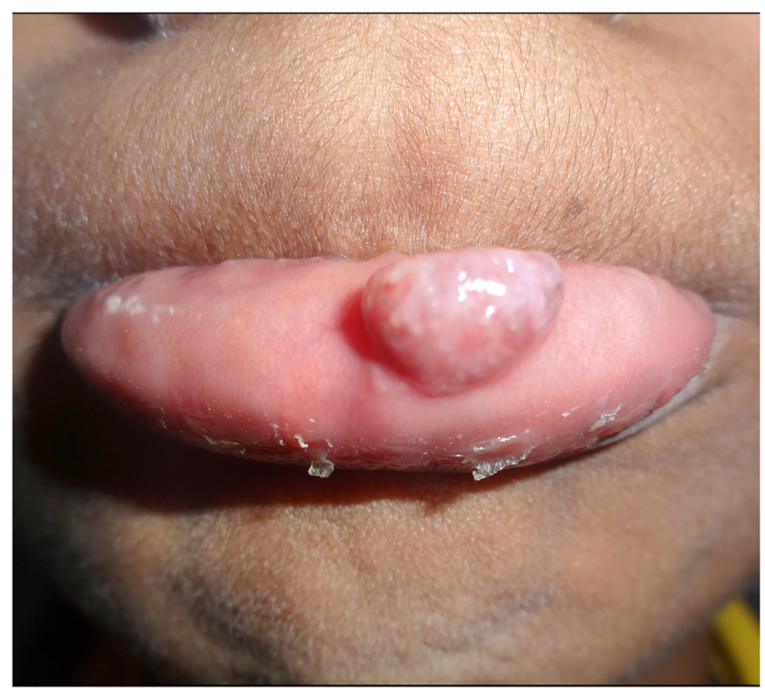

Figure 6 Recurrence of the lesion after 4 weeks.

for soft tissue procedures rather than conventional procedures due to the advantages of good haemostasis and reduced postoperative complications. Hence we decided to treat the patient with a diode laser. Before treating the lesion with laser, Precaine B topical anaesthetic gel (20\% benzocaine) was applied for 2 min prior to infiltration. Local infiltration was given around the lesion (Lignox 2\% a lignocaine with epinephrine 1:80 000). Removal of the lesion was performed using a diode laser (DenLase-810) with a power of 2 watts. The pulse duration was $0.05 \mathrm{~s}$ (figure 3). Laser protective glasses were worn by the patient and the operator before starting the procedure. A circular incision was made around the lesion to obtain a proper biopsy sample. Coagulation of the lesion was achieved after the removal of the lesion (figure 4). Histological examination exhibited a fibrous capsule with central lumen and dense diffuse chronic inflammatory cell infiltration predominately with lymphocytes and plasma cells (figure 5). Hence it was diagnosed as mucocele.

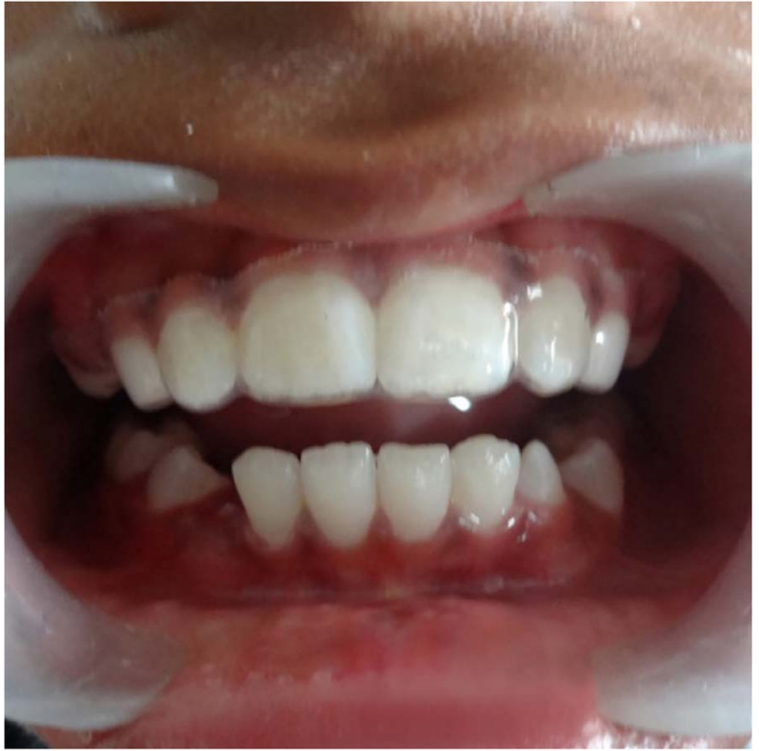

Figure 7 Thermoplasticised splint (erkodur $2 \mathrm{~mm}$ ) placement.

Recurrence of the lesion was observed after 4 weeks in the same region with increased size of $6 \mathrm{~mm}$ in diameter (figure 6). The reason can be attributed to the constant irritation from the maxillary incisors which were in deep bite. Again the lesion was excised using diode laser and a thermoplasticised splint (erkodur $2 \mathrm{~mm}$ ) was used for 6 months as an adjunct to intercept the nail biting habit and also to prevent the irritation of the lip from incisors. Daily rinse with chlorhexidine $0.2 \%$ was advised to maintain good postoperative oral hygiene. The patient has been under observation for 6 months and has not shown any sign of recurrence (figure 7 ).

\section{Learning points}

Diode laser is a therapeutic alternative for treating soft tissues in children, allows good control of haemorrhage and no sutures are required.

- Thermoplasticised splint can be used as an adjunctive therapy to prevent constant irritation from a sharp tooth.

Contributors MC was involved in carrying out the case. AJS was involved in guiding the case. CB assisted the case and PKK was involved in preparation of manuscript.

Competing interests None declared.

Patient consent Obtained.

Provenance and peer review Not commissioned; externally peer reviewed.

\section{REFERENCES}

1 Pedron IG, Galletta VC, Azevedo LH, et al. Treatment of mucocele of the lower lip with diode laser in pediatric patients: presentation of 2 clinical cases. Pediatr Dent 2010:32:539-41.

2 Rangeeth BN, Moses J, Reddy VKK. A rare presentation of mucocele and irritation fibroma of the lower lip. Contemp Clin Dent 2010;1:111-14. 
Copyright 2016 BMJ Publishing Group. All rights reserved. For permission to reuse any of this content visit http://group.bmj.com/group/rights-licensing/permissions.

BMJ Case Report Fellows may re-use this article for personal use and teaching without any further permission.

Become a Fellow of BMJ Case Reports today and you can:

- Submit as many cases as you like

- Enjoy fast sympathetic peer review and rapid publication of accepted articles

- Access all the published articles

- Re-use any of the published material for personal use and teaching without further permission

For information on Institutional Fellowships contact consortiasales@bmjgroup.com

Visit casereports.bmj.com for more articles like this and to become a Fellow 